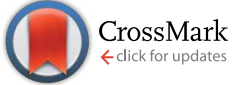

Cite this: DOI: 10.1039/c4tb01071j

Received 1st July 2014

Accepted 14th August 2014

DOI: $10.1039 / c 4 t b 01071 j$

www.rsc.org/MaterialsB

\section{Hyaluronic acid/poly-L-lysine bilayered silica nanoparticles enhance the osteogenic differentiation of human mesenchymal stem cells}

\author{
Sara Amorim, ${ }^{\text {ab }}$ Albino Martins, ${ }^{\text {ab }}$ Nuno M. Neves, ${ }^{\text {ab }}$ Rui L. Reis ${ }^{a b}$ \\ and Ricardo A. Pires*ab
}

Herein, we evaluate the influence of a PLL-HA bilayer on the surface of silica nanoparticles on their capacity to induce the osteogenic differentiation of human bone marrow stem cells (hBMSCs), as a function of their concentration $\left(50 \mu \mathrm{g} \mathrm{mL}^{-1}, 25 \mu \mathrm{g} \mathrm{mL} \mathrm{m}^{-1}\right.$ and $12.5 \mu \mathrm{g} \mathrm{mL}{ }^{-1}$ ). To this purpose, we synthesized silica nanoparticles (diameter of $\sim 250 \mathrm{~nm}$; $\zeta$-potential of $-25 \mathrm{mV}$ ) that were coated with PLL-HA (diameter of $\sim 560 \mathrm{~nm}$; $\zeta$-potential of $-35 \mathrm{mV}$ ). The cell viability, cell proliferation, protein quantification (i.e. MTS, DNA and ALP, respectively) and gene expression (of osteogenesis-related genes: ALP, osteocalcin, collagen type I, bone sialoprotein, Runx-2, osteopontin and osterix) were monitored, for 21 days. We observed the overexpression of most of the tested osteogenic transcripts in the hBMSCs cultured with $\mathrm{SiO}_{2}-\mathrm{PLL}-\mathrm{HA}$, at concentrations of $25 \mu \mathrm{g} \mathrm{mL}-1$ and $12.5 \mu \mathrm{g} \mathrm{mL}^{-1}$. These results indicate that the proposed nanoparticles temporarily improve the osteogenic differentiation of hBMSCs at low nanoparticle concentrations.

\section{Introduction}

Bioceramics, bioactive glasses and related composite materials, that combine bioactive inorganic materials with biodegradable polymers, ${ }^{\mathbf{1}}$ have been extensively studied for biomedical applications. ${ }^{2,3}$ Bioactive materials, in particular silica $\left(\mathrm{SiO}_{2}\right)$ nanoparticles, are considered relevant for bone tissue repair since: (i) they can be easily biofunctionalized; (ii) they are biocompatible (presenting osteoconductive and osteoinductive properties); and (iii) their degradation shows positive biological effects after implantation. ${ }^{4,5}$ In addition, the size of $\mathrm{SiO}_{2}$ nanoparticles can be tuned to match the size range of the integral parts of natural bone, such as hydroxyapatite crystals or cellular compartments, making them promising candidates for bone tissue regeneration. ${ }^{6}$

$\mathrm{SiO}_{2}$ nanoparticles are usually obtained through the sol-gel methodology; they are produced by low-temperature processing, providing the conditions to synthesize nanoparticles of different compositions. In combination, these characteristics enable the preparation of monodispersive $\mathrm{SiO}_{2}$ nanoparticles of different controllable sizes. ${ }^{7}$

Among the different techniques used to modify surfaces, the deposition of polyelectrolyte multilayers (PEMs) has emerged as a very easy handling and versatile tool. Based on the alternate

${ }^{a} 3 B$ 's Research Group-Biomaterials, Biodegradables and Biomimetics, University of Minho, Headquarters of the European Institute of Excellence on Tissue Engineering and Regenerative Medicine, AvePark, 4806-909 Taipas, Guimarães, Portugal

${ }^{b} I C V S / 3 B$ 's-PT Government Associate Laboratory, Braga/Guimarães, Portugal. E-mail: rpires@dep.uminho.pt adsorption of polycations and polyanions, this technique allows films to be built-up with tunable properties. Basically, this technique consists of the dipping of a material in a polyelectrolyte solution, which allows the interactions between a polycation and a polyanion, driving to the construction of a multilayered system. $^{8}$ Several studies have reported the construction of films onto charged surfaces (e.g. gold, $\mathrm{SiO}_{2}$, etc.) using this layer-by-layer (LbL) technique exploiting the opposite charge of poly-L-lysine (PLL) and hyaluronic acid (HA).9,10

The HA is an important component of the natural extracellular matrix (ECM) being present in all tissues. It is a unique, linear, unmodified glycosaminoglycan consisting of repeating disaccharide units composed of D-glucuronic acid and D- $N$ acetylglucosamine. The HA functions not only as a structural component, but it can also bind to cells by direct interaction with cell surface receptors such as CD44. It is able to activate a series of intracellular signaling pathways, participating in the regulation of cell migration, proliferation and differentiation. ${ }^{11,12}$ Some authors defend that HA induces an increase in the mesenchymal stem cell (MSC) differentiation onto the osteogenic lineage. ${ }^{13}$ On the other hand, PLL, a cationic polymer at neutral $\mathrm{pH}$, is commonly used as a cell-adhesion agent for cell-culturing experiments in plates and on other solid substrates. ${ }^{\mathbf{1 4}}$ The cationic primary amine groups of the lysine side chains interact with the negatively charged HA resulting in a multilayered system, well described in the literature. ${ }^{15-17}$

PLL-HA can be chemically cross-linked using water-soluble carbodiimide in combination with $N$-hydroxysulfosuccinimide. This cross-linked (PLL-HA $)_{n}$ system has been reported to 
promote the anchoring of primary chondrocytes and smooth muscle cells, when compared to non cross-linked materials. ${ }^{18}$ $\mathrm{SiO}_{2}$ nanoparticles are known to be efficiently internalized into human MSCs without affecting cell viability, growth or differentiation. ${ }^{19}$ MSCs represent a particularly interesting cell type for research and therapy because of their ability to differentiate into mesodermal lineage cells such as osteocytes, chondrocytes, cardiac muscle, and endothelial cells. ${ }^{20}$ MSCs can been isolated from different organs and tissues, but the most relevant sources are the bone marrow and adipose tissue.

The present work describes the processing of bioactive organic/inorganic nanoparticles, exploiting their chemical and nano-topological structure, and their ability to induce human bone marrow MSC (hBMSC) differentiation towards the osteogenic lineage. Previous studies have reported that cells derived from bone marrow can be stimulated for osteogenesis when in contact with bioactive glasses. ${ }^{21}$ Also, PEM systems, based on PLL-HA are reported to be capable of differentiating MSCs into osteocytes and chondrocytes upon culture with induction factors. ${ }^{22}$ Taking advantage of the physico-chemical characteristics of $\mathrm{SiO}_{2}$ nanoparticles and LbL construction, the overall aim of this work is to synthesize PLL-HA coated $\mathrm{SiO}_{2}$ nanoparticles (Scheme 1) and to investigate their biological activity over viability, proliferation, and differentiation of hBMSCs.

\section{Experimental}

\subsection{Materials}

Tetraethyl orthosilicate 99\% (TEOS), ammonium hydroxide solution (33\%), poly-L-lysine (PLL; $M_{\mathrm{w}} 30-70 \mathrm{kDa}$ ), $N$-(3-dimethylaminopropyl)- $N^{\prime}$-ethylcarbodiimide hydrochloride (EDC) $\geq$ 98.0\% and $N$-hydroxysuccinimide (NHS) were obtained from Sigma-Aldrich. Hyaluronic acid (HA; $M_{\mathrm{w}} 1.20-1.80 \mathrm{MDa}$ ) was purchased from Lifecore. All the chemicals were used without further purification. For immunostaining we used phalloidintetramethylrhodamine B isothiocyanate (P1951) and 4,6-diamidino-2-phenyindole, dilactate (DAPI) (D9564) from SigmaAldrich. Primary antibodies osteocalcin (ab13418 - mousse antihuman) and osteopontin (ab14175 - rabbit anti-human) were purchased from AbCam. Secondary antibodies IgG Alexa Fluor ${ }^{\circledR}$ 488 (A-21202, anti-mouse) and IgG Alexa Fluor® 488 (A21206, anti-rabbit) were obtained from Invitrogen (Life Technologies).

\subsection{Methods}

Synthesis of silica nanoparticles. The synthesis of $\mathrm{SiO}_{2}$ nanoparticles was performed as described elsewhere. ${ }^{23}$ Briefly,

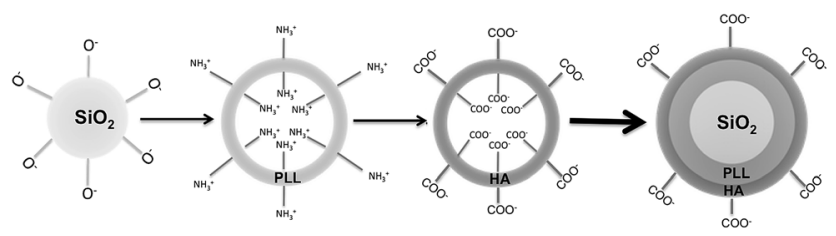

Scheme $1 \mathrm{LbL}$ deposition of PLL and $\mathrm{HA}$ onto the surface of the $\mathrm{SiO}_{2}$ nanoparticles. monodisperse spherical solid core $\mathrm{SiO}_{2}$ nanoparticles were synthesized by mixing $8 \mathrm{~mL}$ of ammonium hydroxide with a solution containing $200 \mathrm{~mL}$ of absolute ethanol and $16 \mathrm{~mL}$ of deionized water. After stirring for $30 \mathrm{~min}, 24 \mathrm{~mL}$ of TEOS was added to the solution and stirred for $6 \mathrm{~h}$ at room temperature. The as-synthesized $\mathrm{SiO}_{2}$ nanoparticle suspension was centrifuged and dried at $70{ }^{\circ} \mathrm{C}$ overnight. The resulting dry powder was further calcined at $550{ }^{\circ} \mathrm{C}$ for $6 \mathrm{~h}$ in air in order to remove organic residues.

Surface coatings. $\mathrm{SiO}_{2}$ nanoparticles were immersed sequentially into a polycation and polyanion solutions, namely PLL (0.5 $\mathrm{mg} \mathrm{mL}^{-1}$ ) and HA $\left(1 \mathrm{mg} \mathrm{mL}^{-1}\right)$, dissolved in $0.15 \mathrm{M}$ $\mathrm{NaCl}(\mathrm{pH} \approx 5.5-6.0)$ to form the polymeric bilayer shell. Each layer was allowed to form for 15 minutes, followed by a set of three rinsing steps using a $0.15 \mathrm{M} \mathrm{NaCl}$ aqueous solution. After the formation of the bilayer, the polymeric shell was crosslinked using a mixture of water-soluble EDC (400 mM) and NHS (100 $\mathrm{mM})$, as described elsewhere. ${ }^{24}$ The nanoparticles were stirred overnight at $4{ }^{\circ} \mathrm{C}$ within the cross-linking solution (prepared with $0.15 \mathrm{M} \mathrm{NaCl}, \mathrm{pH} \approx 5.5-6.0$ ). They were finally rinsed three times with a $0.15 \mathrm{M} \mathrm{NaCl}$ solution, generating the $\mathrm{SiO}_{2}$-bilayer hybrid system $\left(\mathrm{SiO}_{2}-\mathrm{PLL}-\mathrm{HA}\right)$.

Surface morphology, size distribution and $\zeta$-potential measurements. The surface morphology of the nanoparticles was examined using a scanning electron microscope (SEM; Leica S360, Cambridge, UK). The nanoparticles were coated with gold before the analysis. The size distribution of the nanoparticles, and their $\zeta$-potential, were determined by Dynamic Light Scattering (DLS; Malvern, Zetasizer NANO-ZS).

Chemical analysis of the bilayered system. The surface chemistry of the nanoparticles was analyzed by Fourier transform infrared spectroscopy (FTIR). The samples were mixed with potassium bromide $(\mathrm{KBr})$ in a ratio of $1: 10$, sample $: \mathrm{KBr}$ $(\mathrm{w} / \mathrm{w})$. The mixture was molded into a transparent pellet using a press (Pike, USA). Transmission spectra were acquired on an IR Prestige-21 spectrometer (Shimadzu, Japan), using 32 scans, a resolution of $4 \mathrm{~cm}^{-1}$ and a wavenumber range between 4400 $\mathrm{cm}^{-1}$ and $500 \mathrm{~cm}^{-1}$.

Expansion, seeding and osteogenic differentiation of hBMSCs. hBMSCs were isolated from bone marrow aspirates of three donors, under established cooperative agreements between local Hospitals and the 3B's Research Group. The isolation procedure was performed according to the method established by Delorme and Charbord ${ }^{25}$ and the characterization of the mesenchymal phenotype has been described in previous reports. ${ }^{26-28}$ hBMSCs were expanded in basal medium consisting of Dulbecco's modified Eagle's medium (DMEM; Sigma-Aldrich, Germany) supplemented with 10\% heat-inactivated fetal bovine serum (FBS; Biochrom AG, Germany) and 1\% antibiotic/antimyotic solution (final concentration of penicillin 100 units $\mathrm{mL}^{-1}$ and streptomycin $100 \mathrm{mg} \mathrm{mL}^{-1}$; Gibco, UK). Cells were cultured in a $5 \% \mathrm{CO}_{2}$ incubator at $37^{\circ} \mathrm{C}$.

Before the in vitro studies, the $\mathrm{SiO}_{2}-\mathrm{PLL}-\mathrm{HA}$ nanoparticles were sterilized by using ethylene oxide. Confluent hBMSCs, at passage 4 , were harvested, seeded at a density of $1 \times 10^{5}$ cells per well of a 24 well-plate and cultured in the presence of the nanoparticles at concentrations of 50, 25 and $12.5 \mu \mathrm{g} \mathrm{mL}{ }^{-1}$, for 
7, 14 and 21 days under static conditions, in standard osteogenic differentiation medium (basal medium supplemented with $50 \mathrm{mg} \mathrm{mL}^{-1}$ ascorbic acid, $10^{-2} \mathrm{M} \beta$-glycerophosphate and $10^{-7} \mathrm{M}$ dexamethasone). The assay control condition $\left(\mathrm{SiO}_{2}\right.$ nanoparticles without bilayer) at $50 \mu \mathrm{g} \mathrm{mL} \mathrm{mL}^{-1}$ and positive control, were also cultured under standard osteogenic differentiation medium (basal medium supplemented with $50 \mu \mathrm{g}$ $\mathrm{mL}^{-1}$ ascorbic acid, $10 \mathrm{mM} \beta$-glycerophosphate and $10^{-7} \mathrm{M}$ dexamethasone).

Cell morphology and distribution. hBMSC samples were fixed with $2.5 \%$ glutaraldehyde (Sigma, Germany) in phosphate buffer saline solution (PBS; Sigma, Germany) and then dehydrated through an increasing series of ethanol concentrations $(10 \%, 20 \%, 30 \%, 50 \%, 70 \%, 80 \%, 90 \%$ and $100 \%)$ and left to dry overnight. Finally, they were gold sputter-coated (Fisons Instruments SC502, UK) and observed by SEM (Leica S360, Cambridge, UK).

Cell viability and proliferation (MTS assay and DNA content). The hBMSC viability for each culturing time was determined using the Cell Titer $96 \AA$ Aqueous One Solution Cell Proliferation Assay (Promega, USA). This assay is based on the bioreduction of a tetrazolium compound, 3-(4,5-dimethylthiazol-2-yl)-5-(3-carboxymethoxyphe-nyl)-2-(4-sulfofenyl)-2H-tetrazolium (MTS), into a water-soluble brown formazan product. $\mathrm{NADPH}$ or NADH production accomplishes this conversion by the dehydrogenase enzymes in metabolically active cells. The absorbance was measured at $490 \mathrm{~nm}$ using a microplate reader (Synergie HT, Bio-Tek, USA), being related to the quantity of formazan product.

Cell proliferation was quantified by the total amount of double-stranded DNA along the culturing time. Quantification was performed using the Quant-iT PicoGreen ${ }^{\circledR}$ dsDNA Assay Kit (Invitrogen, Molecular Probes, Oregon, USA), according to the manufacturer's instructions. Briefly, hBMSCs were lyzed by osmotic and thermal shock and the supernatant used for the DNA quantification assay. A fluorescent dye, PicoGreen, was used because of its high sensitivity and specificity to doublestranded DNA. The fluorescence of the dye was measured at an excitation wavelength of $485 / 20 \mathrm{~nm}$ and at an emission wavelength of 528/20 nm, in a microplate reader (Synergie HT, BioTek, USA). Triplicates were carried out for each sample and per culturing time. The DNA concentration for each sample was calculated using a standard curve (DNA concentration ranging from 0.0 to $1.5 \mathrm{mg} \mathrm{mL}^{-1}$ ) relating the quantity of DNA with the fluorescence intensity.

Alkaline phosphatase quantification. The concentration of alkaline phosphatase (ALP) was determined for all the culture time periods, using the same samples used for DNA quantification. Briefly, the activity of ALP was assessed using the $p$-nitrophenol assay. Nitrophenyl phosphate disodium salt (pnPP; Fluka BioChemika, Austria), which is colorless, is hydrolyzed by ALP at $\mathrm{pH}=10.5$ and a temperature of $37^{\circ} \mathrm{C}$ to form free $p$-nitrophenol, which is yellow. The reaction was stopped by the addition of $2 \mathrm{M} \mathrm{NaOH}$ (Panreac Quimica, Spain) and the absorbance was read at $405 \mathrm{~nm}$ in a microplate reader (Synergie HT, Bio-Tek, USA). Standards were prepared with 10 $\mu \mathrm{mol} \mathrm{mL}^{-1}$ of $p$-nitrophenol (pNP; Sigma, USA) solution, to obtain a standard curve ranging from 0.0 to $0.3 \mu \mathrm{mol} \mathrm{mL} \mathrm{mL}^{-1}$. Quadruplicates of each sample and standard were used, and the ALP concentrations were calculated from the standard curve.

RNA isolation and real-time quantitative Polymerase Chain Reaction (qPCR). The total RNA was extracted from the hBMSCs using the Tri ${ }^{\circledR}$ reagent (Sigma-Aldrich, USA), according to the manufacturer's instructions. Briefly, at each culturing time, the samples were washed with PBS, immersed in Tri reagent and stored at $-80{ }^{\circ} \mathrm{C}$, until further use. Proteins were removed with chloroform extraction, and the RNA pellets were washed once with isopropyl alcohol and once with $70 \%$ ethanol. Afterwards, the total RNA pellets were reconstituted in RNAse-free water (Gibco, Invitrogen, UK). Reverse transcriptase (RT)-PCR was performed according to the protocol from the iScript cDNA synthesis kit (Quanta BioSciences ${ }^{\mathrm{TM}}$, Gaithersburg, MD, USA). Briefly, a reaction mixture consisting of $1 \mathrm{X}$ iScript reaction mix, $1 \mathrm{~mL}$ iScript reverse transcriptase, RNA template (up to $1 \mathrm{mg}$ total RNA) and nuclease-free water was prepared in $20 \mathrm{~mL}$ of total volume. The single-strand cDNA synthesis occurred by incubating the complete reaction mixture for $5 \mathrm{~min}$ at $25^{\circ} \mathrm{C}$, followed by $30 \mathrm{~min}$ at $42{ }^{\circ} \mathrm{C}$, and was then terminated by an incubation at $85^{\circ} \mathrm{C}$ for $5 \mathrm{~min}$. Amplification of the target cDNA for real-time PCR quantification was performed according to the manufacturer's instructions, using $2 \mathrm{~mL}$ of RT cDNA products, $10^{-6} \mathrm{M}$ of each primer 1XiQSYBR Green Supermix (Quanta BioSciences $^{\mathrm{TM}}$, Gaithersburg, MD, USA) and nuclease-free water, in a final volume of $20 \mu \mathrm{L} .44$ cycles of denaturation $\left(95{ }^{\circ} \mathrm{C}, 10 \mathrm{~s}\right.$ ), annealing (temperature dependent on the gene, $30 \mathrm{~s})$ and extension $\left(72{ }^{\circ} \mathrm{C}, 30 \mathrm{~s}\right)$ were carried out in a Mastercycler Epgradient SRealplex Thermocycler (Eppendorf, Hamburg, Germany) for all genes. The transcripts' expression data were normalized to the housekeeping gene glyceraldehyde3-phosphate-dehygrogenase (GAPDH) and the relative quantification calculated according to the Livak $\left(2^{-\Delta \Delta C T}\right)$ method using the standard osteogenic culture condition as the calibrator.

Immunocytochemistry. Osteopontin (OP) and osteocalcin (OCN) protein expression of hBMSCs was assessed by immunofluorescence to evaluate the osteoblastic differentiation. hBMSCs grown in tissue culture coverslips were fixed in $10 \%$ formalin and stored at $4{ }^{\circ} \mathrm{C}$ in PBS. Samples were permeabilized with $0.025 \%$ of Triton X-100/PBS and washed twice with PBS. A $3 \%$ BSA/PBS solution was used to block unspecific binding of the antibodies, with an incubation of $45 \mathrm{~min}$. Afterwards, samples were incubated in the diluted primary antibody solution (osteopontin $(1: 50)$ or osteocalcin $(1: 25)$ ) in $1 \%$ BSA/PBS solution overnight at $4{ }^{\circ} \mathrm{C}$. Samples were rinsed in permeabilization buffer and washed for $10 \mathrm{~min}$ in PBS, followed by incubation with the respective secondary fluorochrome-conjugated antibody for $2 \mathrm{~h}$ at room temperature in the dark. Finally, samples were incubated with DAPI solution (1/1000), for $15 \mathrm{~min}$ for nuclei staining, followed by incubation with phalloidin (1/100) for cytoskeletal labeling. Samples were washed with PBS before observation. An Olympus FluoView ${ }^{\mathrm{TM}}$ FV1000 confocal laser scanning microscope (CLSM) was used to acquire the images.

Statistical analysis. The normality of the data distribution was evaluated using the Shapiro-Wilk test $(p<0.05)$. Since the 
data did not follow a normal distribution, an initial KruskalWallis test was executed, followed by Dunn's post-test, with a significance level of 95\% (for cell proliferation, viability and ALP activity). For the comparisons between groups, $t$-tests were performed (qPCR). In all cases, * indicates a significant difference with $p<0.05$, ** with $p<0.01$ and *** with $p<0.001$.

\section{Results and discussion}

\subsection{Particles characterization}

$\mathrm{SiO}_{2}$ nanoparticles were synthesized using a Stöber-like approach $^{29}$ in order to obtain a monodisperse particle size distribution. ${ }^{30}$ The $\mathrm{SiO}_{2}$ particle size distribution was determined by DLS (Table 1), confirming their monodispersive character, with an average diameter of $240 \mathrm{~nm}$. The SEM microscopy (Fig. 1) is in agreement with this data, revealing that the nanoparticles present a spherical morphology, with an average diameter of $\sim 250 \mathrm{~nm}$.

The functionalization of the surface of the $\mathrm{SiO}_{2}$ nanoparticles with PLL and HA was executed using the LbL methodology. ${ }^{31-33}$ PLL was used to coat the negatively charged $\mathrm{Si}-\mathrm{OH}$ surface, followed by HA. The assembling of this bilayered system was followed by the $\zeta$-potential of the $\mathrm{SiO}_{2}$ nanoparticles before and after the coating with PLL and PLL-HA (Table 1).

The synthesized $\mathrm{SiO}_{2}$ nanoparticles presented a $\zeta$-potential of $-25 \mathrm{mV}$ at a $\mathrm{pH} \sim 6$, that, upon coating with PLL, changed to $+51 \mathrm{mV}$ due to the positive charge of its amine pending groups. The surface charge is again switched to negative ( $\zeta$-potential of $-35 \mathrm{mV}$ ) with the coating of HA onto the PLL-coated $\mathrm{SiO}_{2}$. These data are complemented with the SEM characterization, which confirms the maintenance of a spherical shape after the PLLHA coating. The SEM image of the $\mathrm{SiO}_{2}-\mathrm{PLL}-\mathrm{HA}$ nanoparticles also revealed that their average diameter is $\sim 400 \mathrm{~nm}$, while the DLS data indicate an average diameter of $567 \mathrm{~nm}$. This mismatch can be explained by the hydration of the polymeric surface bilayer. While the SEM analysis is executed on dry samples and under vacuum, the DLS data are acquired while the nanoparticles are maintained on an aqueous suspension, which enables the hydration of the polymeric coating. In fact, HA is known for its high hydration capacity that increases its dimensions in solution. ${ }^{34}$

The FTIR spectra of PLL, HA, $\mathrm{SiO}_{2}$ and $\mathrm{SiO}_{2}-\mathrm{PLL}-\mathrm{HA}$ are presented in Fig. 2, while the PLL and HA typical IR peaks (with their corresponding assignments) are listed in Table $2 .^{9,35,36}$ The $\nu(\mathrm{NH})$ at $3285 \mathrm{~cm}^{-1}$ is clearly visible in the PLL spectrum, and its contribution to the $\mathrm{SiO}_{2}-\mathrm{PLL}-\mathrm{HA}$ spectrum is observed as a

Table 1 Size and $\zeta$-potential of the $\mathrm{SiO}_{2}, \mathrm{SiO}_{2}-\mathrm{PLL}$ and $\mathrm{SiO}_{2}-\mathrm{PLL}-\mathrm{HA}$ nanoparticles

\begin{tabular}{|c|c|c|c|}
\hline Materials & $\operatorname{Diameter}^{a}(\mathrm{~nm})$ & PDI & $\zeta$-Potential (mV) \\
\hline $\mathrm{SiO}_{2}$ & $240.2 \pm 10.9$ & $0.124 \pm 0.01$ & $-25.0 \pm 0.7$ \\
\hline $\mathrm{SiO}_{2}-\mathrm{PLL}$ & $270.3 \pm 6.7$ & $0.150 \pm 0.01$ & $50.6 \pm 4.1$ \\
\hline $\mathrm{SiO}_{2}-\mathrm{PLL}-\mathrm{HA}$ & $567.6 \pm 6.5$ & $0.120 \pm 0.03$ & $-34.9 \pm 5.2$ \\
\hline
\end{tabular}

${ }^{a}$ Determined by DLS.
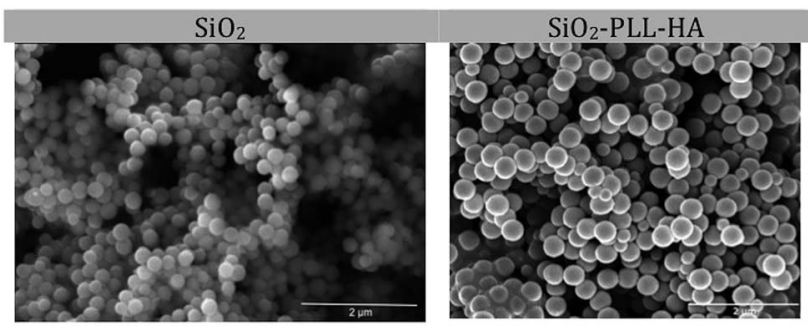

Fig. 1 SEM micrographs of the synthesized $\mathrm{SiO}_{2}$ and $\mathrm{SiO}_{2}-\mathrm{HA}-\mathrm{PLL}$ nanoparticles.

large shoulder to lower wavenumbers of the peak at $3400 \mathrm{~cm}^{-1}$ $\left(\nu(\mathrm{OH})\right.$ from $\mathrm{HA}$ and $\left.\mathrm{SiO}_{2}\right)$. The peaks from the $\nu_{\mathrm{as}}\left(\mathrm{COO}^{-}\right)$of $\mathrm{HA}$ at $1655 \mathrm{~cm}^{-1}$ and from the $\nu(\mathrm{C}=\mathrm{O})$ of PLL at $1658 \mathrm{~cm}^{-1}$ are observed in the spectrum of $\mathrm{SiO}_{2}-\mathrm{PLL}-\mathrm{HA}$ at $1660 \mathrm{~cm}^{-1} \cdot{ }^{36}$ The HA spectrum also reveals its $\nu_{\mathrm{s}}\left(\mathrm{COO}^{-}\right)$at $1411 \mathrm{~cm}^{-1}$, whose contribution to the $\mathrm{SiO}_{2}-\mathrm{PLL}-\mathrm{HA}$ spectrum is in the form of a small shoulder at higher wavenumbers, $1520 \mathrm{~cm}^{-1}$. The asymmetric vibration of the $\nu(\mathrm{SiO})$ with a strong absorption peak at $1090 \mathrm{~cm}^{-1}$ also reveals an enlargement due to the influence of HA characteristic peaks. ${ }^{37}$ Finally, the presence of HA in the $\mathrm{SiO}_{2}-\mathrm{PLL}-\mathrm{HA}$ is further confirmed by the observation in its spectrum of the $\delta\left(\mathrm{COO}^{-}\right)$of $\mathrm{HA}$ at $900 \mathrm{~cm}^{-1}$.

The collected data confirm the synthesis of monodisperse core-shell nanoparticles $\left(\mathrm{SiO}_{2}-\mathrm{PLL}-\mathrm{HA}\right)$ with $\mathrm{SiO}_{2}$ acting as a core and the LbL assembled bilayer of PLL-HA as a shell.

\subsection{Improvement of the hBMSCs' osteogenic differentiation in the presence of the nanoparticles}

Cell morphology, proliferation and viability. The effect of $\mathrm{SiO}_{2}$ concentration on cell viability and proliferation, and particularly on the osteogenic differentiation is widely reported in the literature. Huang et al. ${ }^{5}$ showed that mesoporous $\mathrm{SiO}_{2}$ nanoparticles, at concentrations ranging from 4 to $200 \mu \mathrm{g} \mathrm{mL} \mathrm{m}^{-1}$, do not affect the viability and proliferation of hMSCs. This study concluded that hMSCs exposed to $40 \mu \mathrm{g} \mathrm{mL} \mathrm{m}^{-1}$ of nanoparticles for three days expressed a significant but transient osteogenic signal of ALP. On the other hand, Kim et al. ${ }^{38}$ reported that mRNA expression levels of OCN and OP, evaluated on human adipose-derived stem cells cultured in standard osteogenic differentiation medium, were higher in the medium containing 98.7 $\mu \mathrm{g} \mathrm{mL}^{-1}$ of silicate ions, when compared to $470 \mu \mathrm{g} \mathrm{mL} \mathrm{m}^{-1}$ of silicate ions in the culture medium. Finally, Shen et $a .^{39}$
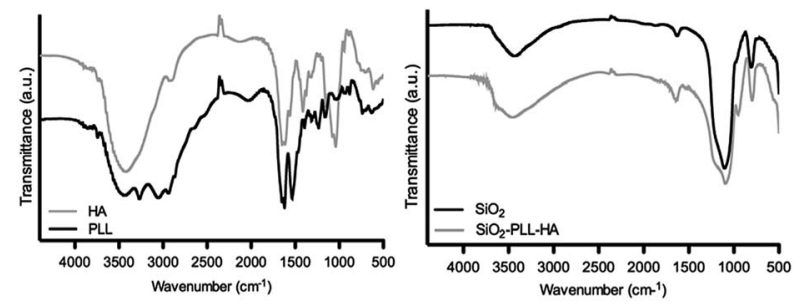

Fig. 2 FTIR spectra of the PLL, HA, $\mathrm{SiO}_{2}$ and $\mathrm{SiO}_{2}-\mathrm{PLL}-\mathrm{HA}$ after crosslinking with EDC-NHS. 
Table 2 Typical vibrational modes of the PLL and HA chemical groups and their wavenumber assignments

\begin{tabular}{ll}
\hline Chemical bond & Wavenumber $\left(\mathrm{cm}^{-1}\right)$ \\
\hline$\nu(\mathrm{OH})$ hydroxyl groups of HA & 3400 \\
$\nu(\mathrm{NH})$ amine groups of PLL & 3285 \\
$\nu(\mathrm{NH})$ amine groups of PLL & 1658 \\
$\nu_{\text {as }}\left(\mathrm{COO}^{-}\right)$carboxylate anion of HA & 1655 \\
$\nu_{\mathrm{s}}\left(\mathrm{COO}^{-}\right)$carboxylate anion of HA & 1411 \\
$\nu\left(\mathrm{COO}^{-}\right)$carboxylate anion of HA & 900
\end{tabular}

demonstrated that $50 \mu \mathrm{g} \mathrm{mL} \mathrm{mL}^{-1}$ of $\mathrm{SiO}_{2}$-based nanoparticles cultured with MSCs successfully differentiated into osteocytes, as demonstrated by ALP activity. Furthermore, this $\mathrm{SiO}_{2}$ concentration did not significantly affect cell viability and proliferation. Based on these results, $50 \mu \mathrm{g} \mathrm{mL^{-1 }}$ was set as the maximum concentration of nanoparticles in the culture medium for the present study.

The synthesized nanoparticles were seeded directly onto cultured hBMSCs, for different time periods (7, 14 and 21 days) and investigated in terms of their genotypic and phenotypic features. The morphology of hBMSCs in contact with $\mathrm{SiO}_{2}$ and $\mathrm{SiO}_{2}$-PLL-HA $\left(50,25\right.$ and $12.5 \mu \mathrm{g} \mathrm{mL}{ }^{-1}$, named $\mathrm{SiO}_{2}-\mathrm{PLL}-\mathrm{HA}$, $\mathrm{SiO}_{2}-\mathrm{PLL}-\mathrm{HA}(1 / 2)$ and $\mathrm{SiO}_{2}-\mathrm{PLL}-\mathrm{HA}(1 / 4)$, respectively) was analysed by SEM (Fig. 3). The hBMSCs exhibited the typical spindle-shape morphology and cell-to-cell interactions were also observed as previously reported. ${ }^{40}$

The effect of $\mathrm{SiO}_{2}$-PLL-HA nanoparticles, at different concentrations, on hBMSC proliferation was also assessed by measuring the total cells' DNA (Fig. 4). Previous studies of hBMSC response to $\mathrm{SiO}_{2}$ nanoparticles revealed no evidence of cytotoxicity for 1-3 days of incubation..$^{5,39,41}$ From our data, the same behaviour is observed at days 7, 14 and 21 for the silica

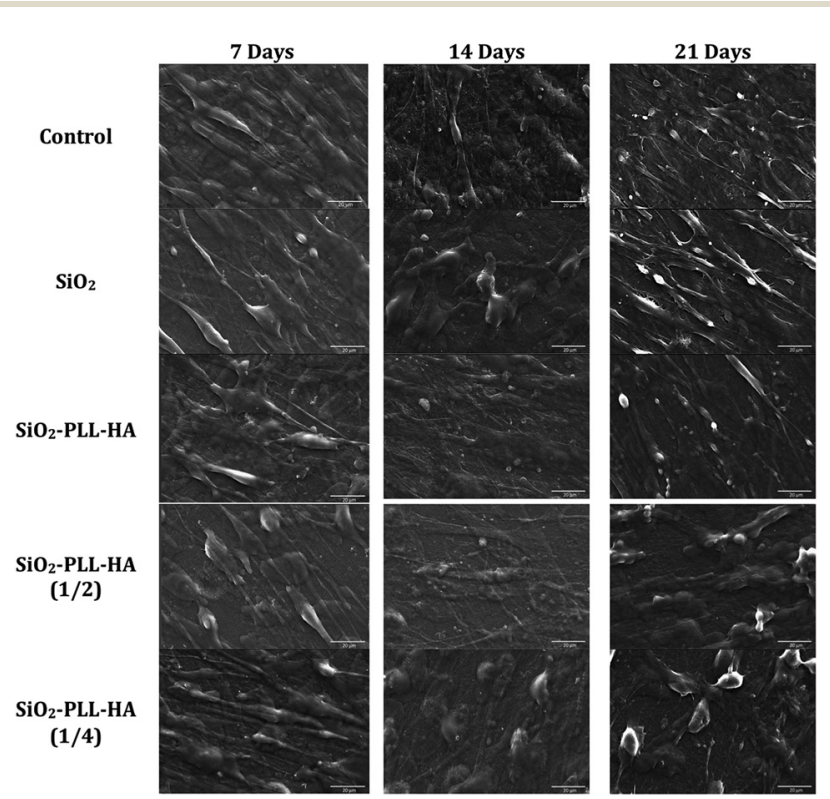

Fig. 3 SEM micrographs of the morphology of hBMSCs cultured for 7 , 14 and 21 days with $\mathrm{SiO}_{2}$ and $\mathrm{SiO}_{2}-\mathrm{PLL}-\mathrm{HA}$ nanoparticles. and bilayered silica nanoparticles at all studied concentrations. Furthermore, hBMSC proliferation results do not show statistically significant differences between the cells cultured with and without nanoparticles at the same time points.

A metabolic activity-based assay (MTS) was also performed at the different time points, in order to determine the hBMSC viability when cultured in osteogenic culture medium. MTS results are directly proportional to the number of living cells. ${ }^{42}$ Our results (Fig. 4) indicate that, at day $7, \mathrm{SiO}_{2}$ nanoparticles at a concentration of $50 \mu \mathrm{g} \mathrm{mL} \mathrm{m}^{-1}$ show a higher viability when compared to the osteogenic control, indicating that those nanoparticles are not cytotoxic. At the same time point, the hBMSCs cultured with $\mathrm{SiO}_{2}-\mathrm{PLL}-\mathrm{HA}(1 / 2)$ and $\mathrm{SiO}_{2}-\mathrm{PLL}-$ $\mathrm{HA}(1 / 4)$ nanoparticles present a highly significant increase on viability, when compared to the control. These conditions have a different behavior than the $\mathrm{SiO}_{2}$-PLL-HA. In the latter case, the cells present a viability comparable to the control. Therefore, a lower concentration of bilayered silica nanoparticles induces a higher hBMSC metabolic activity. At day 21, no significant differences were observed, except for $\mathrm{SiO}_{2}-\mathrm{PLL}-\mathrm{HA}$ which presents a significantly lower $(p<0.05)$ metabolic activity than the cells cultured with $\mathrm{SiO}_{2}-\mathrm{PLL}-\mathrm{HA}(1 / 2)$.

Genotypic characterization of differentiated hBMSCs. Complementary to the reported biological data, the differentiation level of hBMSCs cultured with $\mathrm{SiO}_{2}$ and $\mathrm{SiO}_{2}-\mathrm{PLL}-\mathrm{HA}$ nanoparticles was assessed by quantitative PCR of some bonespecific gene transcripts, namely, ALP, OP, OCN, bone sialoprotein (BSP), osterix (OSX), Runx-related transcription factor 2 (Runx-2) and collagen type I $(\operatorname{Col} \alpha)$. The relative expression of those genes was normalized against the housekeeping gene GAPDH and the standard osteogenic culture condition was used as the calibrator. It is well described that the osteogenic differentiation can be subdivided into several developmental stages: proliferation of stem cells, ECM synthesis, maturation and ECM mineralization, each with characteristic changes in the gene expressions rates. ${ }^{43}$

In this study, each selected gene is responsible for different stages of differentiation. The transcription factor Runx-2 is a crucial early marker of the MSCs commitment at the osteogenic lineage. Runx-2 up-regulates BSP and OCN, two major components of the bone ECM synthesized exclusively by osteoblastic cells. ${ }^{44}$ While BSP is an osteoblast-enriched gene, ${ }^{45} \mathrm{OCN}$ is the major non-collagenous protein component of bone ECM and secreted exclusively by osteoblastic cells at the late stage of

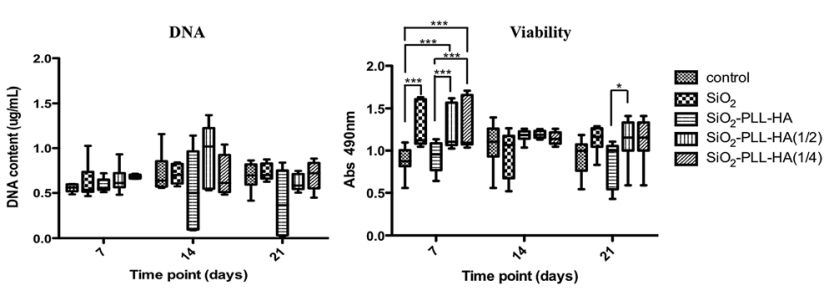

Fig. 4 hBMSC proliferation (DNA quantification) and viability (MTS quantification) at 7,14 , and 21 days after seeding. Significant differences were represented by $*$ for $p<0.05, * *$ for $p<0.01$ and $* * *$ for $p<$ 0.001 , as determined by the statistical analysis. 
maturation, and therefore is considered as an indicator of osteoblast differentiation. ${ }^{46}$

From the PCR data (Fig. 5) it is clear that there is an upregulation of Runx-2 in the cells cultured with $\mathrm{SiO}_{2}$-PLL$\mathrm{HA}(1 / 4)$ at 14 days and $\mathrm{SiO}_{2}-\mathrm{PLL}-\mathrm{HA}(1 / 2)$ at 7 days. In fact, the OCN and BSP (usually linked to the Runx-2 expression) are also overexpressed at the same time point and bilayered nanoparticles' concentration. Unexpectedly, at higher nanoparticle concentrations, $\mathrm{SiO}_{2}-\mathrm{PLL}-\mathrm{HA}$, we did not observe the same trend in the Runx-2 expression. These observations might be related to the overexpression of Runx- 2 in between the time points chosen for this study, which would limit its detection by PCR. In the $\mathrm{SiO}_{2}$ case, Runx-2 is overexpressed at 7 days of culture, although the up-regulation of OCN and BSP is not observed for $\mathrm{SiO}_{2}$ at any time point. Our data indicate that the $\mathrm{SiO}_{2}-\mathrm{PLL}-\mathrm{HA}(1 / 2)$ and $\mathrm{SiO}_{2}-\mathrm{PLL}-\mathrm{HA}(1 / 4)$ present the most consistent enhancement of the hBMSC osteogenic differentiation, through the early osteogenic marker Runx-2, which also promotes the overexpression of the BSP and OCN genes.

OSX is one of the few characterized osteoblast specific genes. ${ }^{47}$ It is known to be a specific osteogenic transcription
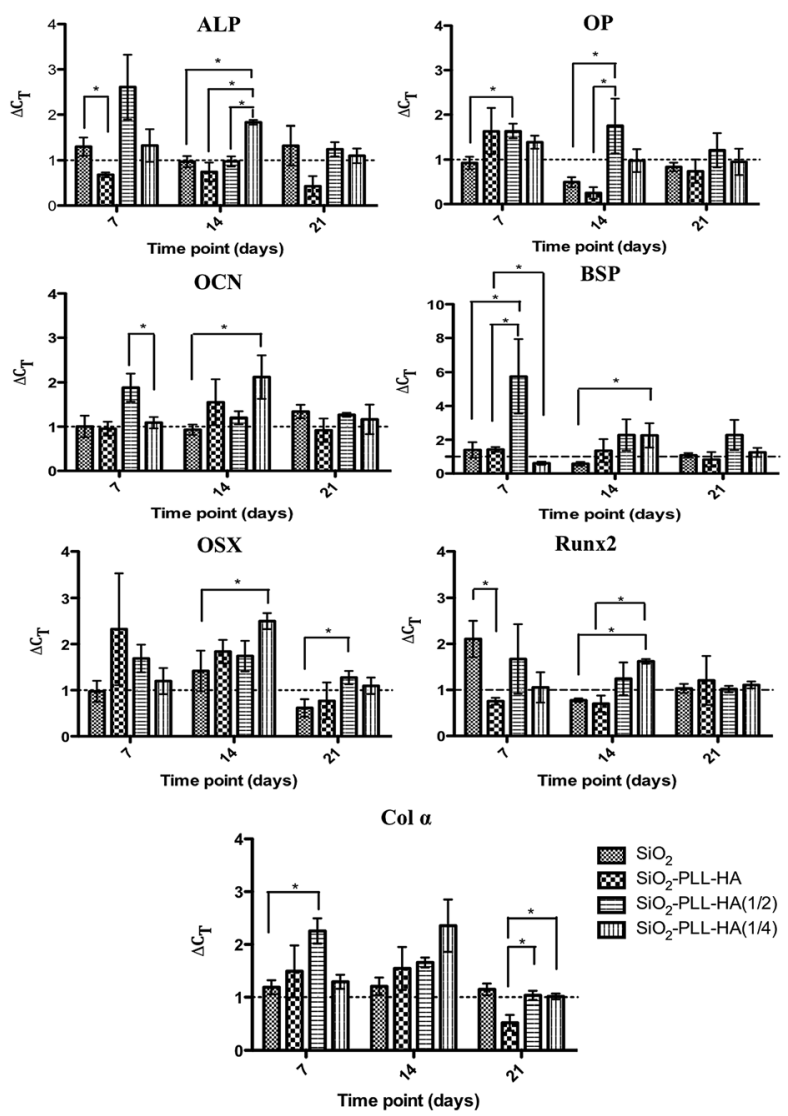

Fig. 5 Relative expression of bone-specific transcripts, namely ALP, OP, BSP, OCN, Runx-2, OSX and Col $\alpha$ by hBMSCs induced the differentiation into the osteogenic lineage over 21 days. The results are expressed as the means $\pm \mathrm{SD},(*)$ indicating a significant difference with $p<0.05,(* *) p<0.01$, and $(* * *) p<0.001$. The dashed line indicates the normalized gene expression of the standard osteogenic culture conditions. factor, which is identified as a late bone marker required for the differentiation of preosteoblasts into fully functioning osteoblasts. ${ }^{48}$ The OSX gene expression results showed that, at day 14 , $\mathrm{SiO}_{2}-\mathrm{PLL}-\mathrm{HA}(1 / 4)$ presents the highest OSX overexpression, which indicates higher osteogenic activity. These results are consistent with the observed overexpression of the OCN and BSP under the same culture conditions (i.e. 14 days and $\mathrm{SiO}_{2}-$ PLL-HA(1/4)).

OP performs important bone related functions, although, it cannot be considered bone specific since it also plays roles in kidneys, epithelial lining tissues, blood plasma, and breast milk. ${ }^{47}$ Despite this, its gene expression evaluation was not discarded. OP appears up-regulated mostly at days 7 and 14 for the $\mathrm{SiO}_{2}-\mathrm{PLL}-\mathrm{HA}(1 / 2)$ condition. The $\mathrm{Col} \alpha$, as OP, cannot be considered bone specific, having been identified in numerous unrelated cell types. However, it is expressed at high levels near to the end of the proliferative period, which occurs until day 7 of culture, and during the period of ECM deposition and maturation. ${ }^{49}$ In fact, Col $\alpha$ gene expression is up-regulated mainly at day 14 in the presence of $\mathrm{SiO}_{2}-\mathrm{PLL}-\mathrm{HA}(1 / 4)$ and at day 7 for the $\mathrm{SiO}_{2}-\mathrm{PLL}-\mathrm{HA}(1 / 2)$. This observation is in accordance with its typical early stage expression.

Finally, another bone non-specific gene is the ALP, which is also expressed at the early stages of the osteogenic differentiation. At day 7 and 14 we registered an increase of ALP expression in the cells cultured in the presence of $\mathrm{SiO}_{2}-\mathrm{PLL}-\mathrm{HA}(1 / 2)$ and $\mathrm{SiO}_{2}-\mathrm{PLL}-\mathrm{HA}(1 / 4)$, respectively. These observations are consistent with the overexpression of the other monitored genes for the same samples, which also showed an up-regulation of genes Runx-2, OSX, OCN, BSP and Col $\alpha$, at the same time points. Summarizing, the gene expression shows relevant differences in coated silica nanoparticles with PLL-HA, at lower concentrations, than the $\mathrm{SiO}_{2}$ nanoparticles. In fact, Manferdini et al. ${ }^{50}$ described that the biomimetic treatment of an HA-based scaffold promotes a faster mineralization process, suggesting its possible use in clinics as a support for improving bone repair.

ALP activity quantification. ALP, an early stage marker of osteogenic differentiation, is an enzyme belonging to a group of membrane-bound glycoproteins, involved in the pathway resulting in the deposition of minerals on ECM molecules. ${ }^{51}$ The ALP activity of hBMSCs was assessed as an indicator of the osteogenic differentiation. Fig. 6 presents the ALP protein activity expression profiles ( $\mu \mathrm{mol}$ ALP per mg protein) of cultured hBMSCs. The results show that ALP activity values increase progressively with time under all the different experimental conditions, except for the $\mathrm{SiO}_{2}-\mathrm{PLL}-\mathrm{HA}$ that presents a peak at day 14 and a decrease in the following time point (this is also in accordance with the gene expression analysis, where the ALP gene expression is downregulated mainly at the latter time points).

In general, the cells' ALP genetic expression is usually observed before the ALP is actually synthesized by the cells. In this context, and analyzing these data in combination with the ALP genetic expression profiles, an increase on the activity of the protein at higher time points would be expected, as observed for the cells cultured in the presence of lower concentration of bilayered nanoparticles, i.e. $\mathrm{SiO}_{2}-\mathrm{PLL}-\mathrm{HA}(1 / 2)$ and $\mathrm{SiO}_{2}-\mathrm{PLL}-\mathrm{HA}(1 / 4)$. 
ALP activity quantification

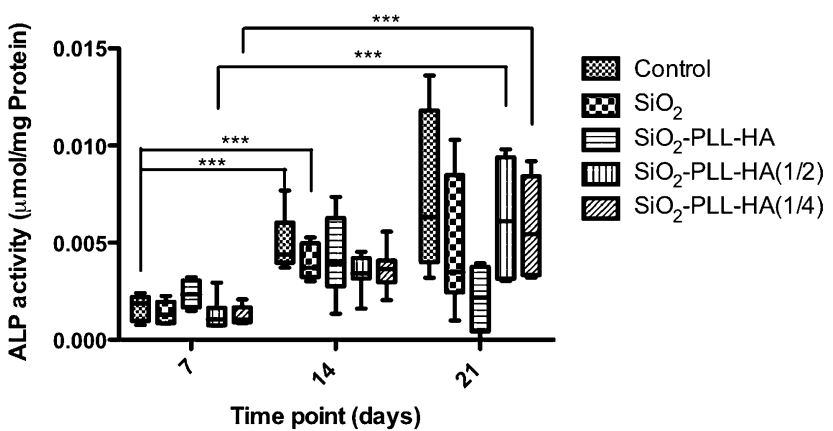

Fig. 6 ALP activity of hBMSCs cultured with $\mathrm{SiO}_{2}$ and $\mathrm{SiO}_{2}-\mathrm{PLL}-\mathrm{HA}$ nanoparticles at time points 7,14 and 21 days, under osteogenic induction.

Phenotypic characterization of differentiated hBMSCs. The immunofluorescence staining of matrix-associated proteins (OCN and OP) were used as markers of hBMSCs osteoblastic differentiation. OCN, a bone-specific glycoprotein that binds calcium and may promote calcification of the bone ECM, has been used as a late marker of the osteogenic differentiation. ${ }^{52}$ OP, synthesized by bone forming cells, is also a phosphoprotein that possesses several calcium-binding domains and is associated with cell attachment, proliferation, and mineralization of the bone ECM. ${ }^{52}$ Fig. 7 shows the fluorescence of the OP and OCN markers.

In the case of $\mathrm{OP}$, as expected, a delay in the protein synthesis and its genetic expression is observed. In fact, in all the cases, there is an initial higher genetic expression (PCR data) that is accompanied by the protein synthesis at a latter stage. As an example we observe an OP genetic overexpression

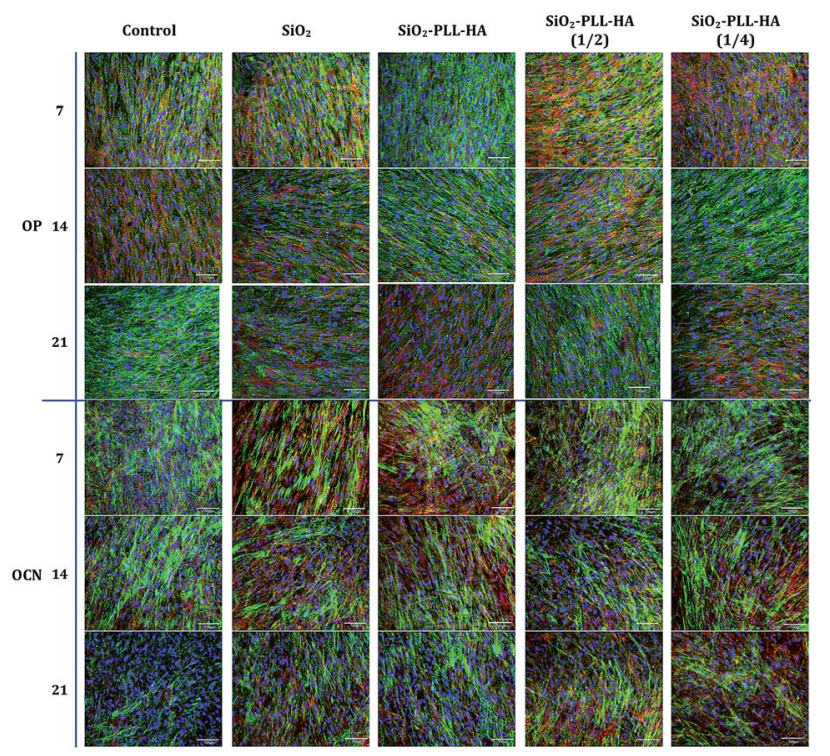

Fig. 7 Confocal micrographs of the hBMSCs cultured in the presence of nanoparticles for 21 days. Nuclei were stained in blue, actin in red and OP or OCN in green. (compared to the control group) in days 7 and 14 for the $\mathrm{SiO}_{2}-$ PLL-HA(1/2) that is followed by a higher OP fluorescence in the cell culture at day 21 .

In the case of OCN expression, its deposition in the ECM under all cultured conditions is clearly visible. Again the genetic up-regulation occurs at earlier time points (day 7 or 14) for the $\mathrm{SiO}_{2}-\mathrm{PLL}-\mathrm{HA}, \mathrm{SiO}_{2}-\mathrm{PLL}-\mathrm{HA}(1 / 2)$ and $\mathrm{SiO}_{2}-\mathrm{PLL}-\mathrm{HA}(1 / 4)$ nanoparticles, although, the increase in the OP fluorescence is only observed at day 21 (compared to the control sample). This is again in accordance with the different timeframes of genetic expression and protein deposition, as previously explained.

\section{Conclusions}

Herein was demonstrated that the proposed $\mathrm{SiO}_{2}$ bilayered system is able to improve the in vitro osteogenic differentiation of hBMSCs, which is dependent on the nanoparticle concentration, without detrimental effect over cell viability and proliferation. An early in time overexpression of ALP, OCN, OP, BSP, OSX, Runx-2 and Col $\alpha$ was observed when bilayered nanoparticles were used in the culture medium. The highest overexpression of these osteogenesis-related genes was observed at lower concentrations of nanoparticles $\left(25 \mu \mathrm{g} \mathrm{mL} \mathrm{L}^{-1}\right.$ and $12.5 \mu \mathrm{g} \mathrm{mL}{ }^{-1}$ ), being an indication of their osteoinduction activity. The study shows that bi-layered silica nanoparticles at low concentrations are potential candidates for applications in regenerative medicine. These systems can be used as injectable or a useful component of scaffolds for bone tissue regeneration approaches.

\section{Acknowledgements}

We acknowledge funding from the European Union Seventh Framework Programme (FP7/2007-2013) under grant agreement number REGPOT-CT2012-316331-POLARIS. AM acknowledges QREN (project "RL1-ABMR-NORTE-01-0124-FEDER-000016" cofinanced by the North Portugal Regional Operational Programme (ON.2, "O Novo Norte") under the NSRF through the ERDF) for financing this research work.

\section{References}

1 L.-C. Gerhardt and A. R. Boccaccini, Materials, 2010, 3, 38673910.

2 R. Jugdaohsingh, J. Nutr., Health Aging, 2009, 11, 99-110.

3 B. Lei, X. Chen, X. Han and J. Zhou, J. Mater. Chem., 2012, 22, 16906-16913.

4 B. Lei, X. Chen, X. Han and Z. Li, J. Mater. Chem., 2011, 21, 12725-12734.

5 D. Huang, T. Chung, Y. Hung, F. Lu, S.-H. Wu, C.-Y. Mou, M. Yao and Y.-C. Chen, Toxicol. Appl. Pharmacol., 2008, 231, 208-215.

6 A. Tautzenberger, A. Kovtun and A. Ignatius, Int. J. Nanomed., 2012, 7, 4545-4557.

7 J. Y. Wen and G. L. Wilkes, Chem. Mater., 1996, 8, 1667-1681. 
8 L. Richert, F. Boulmedais, P. Lavalle, J. Mutterer, E. Ferreux, G. Decher, P. Schaaf, J.-C. Voegel and C. Picart, Biomacromolecules, 2004, 5, 284-294.

9 L. Shen, P. Chaudouet, J. Ji and C. Picart, Biomacromolecules, 2011, 12, 1322-1331.

10 C. Picart, P. Lavalle, P. Hubert, F. J. G. Cuisinier, G. Decher, P. Schaaf and J. C. Voegel, Langmuir, 2001, 17, 7414-7424.

11 L. Zou, X. Zou, L. Chen, H. Li, T. Mygind, M. Kassem and C. Bünger, J. Orthop. Res., 2008, 26, 713-720.

12 J. Patterson, R. Siew, S. W. Herring, A. S. Lin, R. Guldberg and P. S. Stayton, Biomaterials, 2010, 31, 6772-6781.

13 T. Sasaki and C. Watanabe, Bone, 1995, 16, 9-15.

14 V. Krikorian, M. Kurian, M. E. Galvin, A. P. Nowak, T. J. Deming and D. J. Pochan, J. Polym. Sci., Part B: Polym. Phys., 2002, 40, 2579-2586.

15 L. Jourdainne, S. Lecuyer, Y. Arntz, C. Picart, P. Schaaf, B. Senger, J.-C. C. Voegel, P. Lavalle and T. Charitat, Langmuir, 2008, 24, 7842-7847.

16 L. Richert, A. Schneider, D. Vautier, C. Vodouhe, N. Jessel, E. Payan, P. Schaaf, J. C. Voegel and C. Picart, Cell Biochem. Biophys., 2006, 44, 273-285.

17 T. Boudou, T. Crouzier, R. Auzely-Velty, K. Glinel and C. Picart, Langmuir, 2009, 25, 13809-13819.

18 A. Engler, L. Richert, J. Wong, C. Picart and D. Discher, Surf. Sci., 2004, 570, 142-154.

19 A. K. Gaharwar, S. M. Mihaila, A. Swami, A. Patel, S. Sant, R. L. Reis, A. P. Marques, M. E. Gomes and A. Khademhosseini, Adv. Mater., 2013, 25, 3329-3336.

20 G. Brooke, M. Cook, C. Blair, R. Han, C. Heazlewood, B. Jones, M. Kambouris, K. Kollar, S. McTaggart, R. Pelekanos, A. Rice, T. Rossetti and K. Atkinson, Semin. Cell Dev. Biol., 2007, 18, 846-858.

21 M. Amaral, M. A. Costa, M. A. Lopes, R. F. Silva, J. D. Santos and M. H. Fernandes, Biomaterials, 2002, 23, 4897-4906.

22 O. V. Semenov, A. Malek, A. G. Bittermann, J. Voros and A. H. Zisch, Tissue Eng., Part A, 2009, 15, 2977-2990.

23 S. B. Yoon, J.-Y. J. H. Kim, Y. J. Park, K. R. Yoon, S.-K. Park and J.-S. Yu, J. Mater. Chem., 2007, 17, 1758.

24 K. Ren, L. Fourel, C. G. Rouviere, C. Albiges-Rizo and C. Picart, Acta Biomater., 2010, 6, 4238-4248.

25 B. Delorme and P. Charbord, Methods Mol. Med., 2007, 140, 67-81.

26 M. L. Alves da Silva, A. Martins, A. R. Costa-Pinto, V. M. Correlo, P. Sol, M. Bhattacharya, S. Faria, R. L. Reis and N. M. Neves, J. Tissue Eng. Regener. Med., 2011, 5, 722732.

27 N. Monteiro, A. Martins, D. Ribeiro, S. Faria, N. A. Fonseca, J. N. Moreira, R. L. Reis and N. M. Neves, J. Tissue Eng. Regener. Med., 2013, DOI: 10.1002/term.1817.

28 A. R. Costa-Pinto, V. M. Correlo, P. C. Sol, M. Bhattacharya, P. Charbord, B. Delorme, R. L. Reis and N. M. Neves, Biomacromolecules, 2009, 10, 2067-2073.
29 I. Ibrahim, A. Zikry and M. Sharaf, The Journal of American Science, 2010, 6, 985-989.

30 J. Chruściel and L. Ślusarski, Mater. Sci., 2003, 21, 461-469.

31 R. V. Klitzing, Phys. Chem. Chem. Phys., 2006, 8, 5012-5033.

32 A. P. R. R. Johnston, C. Cortez, A. S. Angelatos and F. Caruso, Curr. Opin. Colloid Interface Sci., 2006, 11, 203-209.

33 J. Jaber and J. Schlenoff, Curr. Opin. Colloid Interface Sci., 2006, 11, 324-329.

34 R. Novoa-Carballal, D. V. Pergushov and A. H. E. Müller, Soft Matter, 2013, 9, 4297.

35 K. Haxaire, Y. Maréchal, M. Milas and M. Rinaudo, Biopolymers, 2003, 72, 10-20.

36 M. Rozenberg and G. Shoham, Biophys. Chem., 2007, 125, 166-171.

37 A. Beganskienè and V. Sirutkaitis, Mater Sci., 2004, 10, 287290.

38 K. Kim, J. Lee, S. Lee and J. Rhie, J. Tissue Eng. Regener. Med., 2010, 7, 171-177.

39 Y. Shen, Y. Shao, H. He and Y. Tan, Int. J. Nanomed., 2013, 8, 119-127.

40 P. Han, C. Wu and Y. Xiao, Biomater. Sci., 2013, 1, 379-392.

41 S. Labbaf, O. Tsigkou, K. H. Müller, M. M. Stevens, A. E. Porter and J. R. Jones, Biomaterials, 2011, 32, 10101018.

42 A. Zonari, S. Novikoff, N. R. P. Electo, N. M. Breyner, D. A. Gomes, A. Martins, N. M. Neves, R. L. Reis and A. M. Goes, PLoS One, 2012, 7, e35422.

43 D.-M. Huang, Y. Hung, B.-S. Ko, S.-C. Hsu, W.-H. Chen, C.-L. Chien, C.-P. Tsai, C.-T. Kuo, J.-C. Kang, C.-S. Yang, C.-Y. Mou and Y.-C. Chen, FASEB J., 2005, 19, 20142016.

44 A. Polini, D. Pisignano, M. Parodi, R. Quarto and S. Scaglione, PLoS One, 2011, 6, e26211.

45 M-T. Tsai, Y-S. Lin, W-C. Chen, C-H. Ho, H-L. Huang and $\mathrm{J}-\mathrm{T}$. HSu, Proceedings of the World Congress on Engineering, 2011, 3, 2690-2694.

46 G. Kirkham, S. Cartmell and N. Ashammakhi, in Topics in Tissue Engineering, ed. N. Ashammakhi, R. Reis and E.Chiellini, 2007, vol. 3.

47 E. Kärner, C. Bäckesjö and J. Cedervall, Biochim. Biophys. Acta, Gen. Subj., 2009, 1790, 110-118.

48 N. Chevallier, F. Anagnostou, S. Zilber, G. Bodivit, S. Maurin, A. Barrault, P. Bierling, P. Hernigou, P. Layrolle and H. Rouard, Biomaterials, 2010, 31, 270-278.

49 M. Sila-Asna, A. Bunyaratvej, S. Maeda, H. Kitaguchi and N. Bunyaratavej, Kobe J. Med. Sci., 2007, 53, 25-35.

50 C. Manferdini, V. Guarino, N. Zini, M. G. Raucci, A. Ferrari, F. Grassi, E. Gabusi, S. Squarzoni, A. Facchini, L. Ambrosio and G. Lisignoli, Biomaterials, 2010, 31, 3986-3996.

51 J. L. Whyte, S. G. Ball, C. A. Shuttleworth, K. Brennan and C. M. Kielty, Stem Cell Res., 2011, 6, 238-250.

52 G. Karsenty, Genes Dev., 1999, 13, 3037-3051. 